\author{
JERZY BIELUK ${ }^{1}$
}

\title{
Regulacja prawna integrowanej ochrony roślin
}

\section{Zagadnienia wstępne}

Jednym z priorytetów wspólnej polityki rolnej są działania związane z ochroną środowiska, jakością środowiska i jakością produktów spożywczych. Wyrazem tej polityki jest szereg aktów prawnych Unii Europejskiej. Regulacje prawne Parlamentu Europejskiego i Rady, będące odpowiedzią na stale rosnące wymagania w powyższym zakresie, nadają specjalny status integrowanej ochronie roślin. Podstawowymi aktami prawa europejskiego w tym przedmiocie, do stosowania których od 1 stycznia 2014 r. zobowiązana jest również Polska, są:

1) Dyrektywa Parlamentu Europejskiego i Rady 2009/128/WE uchwalona przez Parlament Europejski 21 października 2009 roku ustanawiająca ramy wspólnotowego działania na rzecz zrównoważonego stosowania pestycydów; ${ }^{2}$

2) Rozporządzenie Parlamentu Europejskiego i Rady (WE) nr 1107/2009 uchwalone przez Parlament Europejski 21 października 2009 r. dotyczące wprowadzenia do obrotu środków ochrony roślin i uchylające Dyrektywy Rady 79/117/EWG i 91/414/EWG. ${ }^{3}$

Zgodnie z Rozporządzeniem Parlamentu Europejskiego i Rady (WE) nr 1107/2009 „W celu zapewnienia wysokiego poziomu ochrony zdrowia ludzi i zwierząt oraz środowiska, środki ochrony roślin powinny być stosowane w sposób właściwy, zgodnie $\mathrm{z}$ wydanym zezwoleniem, $\mathrm{z}$ uwzględnieniem zasad integrowanej ochrony roślin, przy czym zawsze wtedy, gdy jest to możliwe, priorytetowo należy traktować niechemiczne i naturalne rozwiązania alternatywne."

Już na wstępie Dyrektywy Parlamentu Europejskiego i Rady 2009/128/WE zostało również podkreślone, że „Państwa członkowskie powinny opisać w ich krajowych planach działania, w jaki sposób zapewniają wprowadzanie w życie zasad integrowanej ochrony roślin, dając, tam gdzie to możliwe, pierwszeństwo nieche-

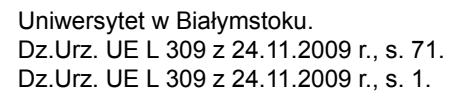


micznym metodom ochrony roślin, ochrony przed szkodnikami i zarządzania uprawami.".

Widoczna jest więc tendencja do promowania w regulacjach unijnych zrównoważonych praktyk rolniczych, takich jak integrowana ochrona roślin, których zadaniem jest osiągnięcie równowagi pomiędzy produkcją rolniczą a ochroną środowiska.

Celem niniejszej publikacji jest przedstawienie podstawowych założeń prawnych integrowanej ochrony roślin na poziomie europejskim oraz sposób regulacji powyższej problematyki w Polsce.

\section{Pojęcie integrowanej ochrony roślin}

Przez integrowaną ochronę roślin zgodnie z Dyrektywą Parlamentu Europejskiego i Rady 2009/128/WE należy rozumieć „staranne rozważenie wszystkich dostępnych metod ochrony roślin, a następnie przedsięwzięcie właściwych środków mających na celu zahamowanie rozwoju populacji organizmów szkodliwych oraz utrzymanie stosowania środków ochrony roślin i innych form interwencji na ekonomicznie i ekologicznie uzasadnionym poziomie, a także zmniejszenie lub zminimalizowanie zagrożenia dla zdrowia ludzi i dla środowiska. «Integrowana ochrona roślin» kładzie nacisk na uzyskanie zdrowych plonów przy minimalnych zakłóceniach funkcjonowania ekosystemu rolniczego i zachęca do stosowania naturalnych sposobów zwalczania szkodników". ${ }^{4}$

Podstawy integrowanej ochrony roślin są wynikiem poszukiwania rozwiązań, które pozwalają zapewnić odpowiedni poziom ochrony upraw przed organizmami szkodliwymi, co pozwala na zachowanie opłacalności ekonomicznej produkcji rolniczej, a jednocześnie umożliwiają ograniczenie stosowania chemicznych środków ochrony roślin do niezbędnego minimum. Analizowane podejście do ochrony roślin polega na stosowaniu wszystkich dostępnych metod - w szczególności zaś metod niechemicznych - co pozwala na zminimalizowanie zagrożenia dla zdrowia ludzi, zwierząt oraz środowiska. Integrowana ochrona roślin wiąże się z wykorzystaniem wiedzy o organizmach szkodliwych dla roślin, zwłaszcza o biologii i szkodliwości tych organizmów, co umożliwia określenie optymalnych okresów podejmowania czynności, mających na celu ich zwalczanie. Korzysta się tu także z naturalnie występujących organizmów pożytecznych, w tym drapieżników i pasożytów organizmów szkodliwych dla roślin oraz ich introdukcji. ${ }^{5}$ 
Ogólne zasady integrowanej ochrony roślin, których stosowanie przez wszystkich profesjonalnych użytkowników środków ochrony roślin jest wymagane od dnia 1 stycznia 2014 r., wynikają z załącznika III do Dyrektywy Parlamentu Europejskiego i Rady 2009/128/WE. Zgodnie z tymi zasadami „Zapobieganie występowaniu organizmów szkodliwych lub minimalizowanie ich negatywnego wpływu na rośliny uprawne należy osiągać lub wspierać między innymi przez:

- płodozmian,

- stosowanie właściwych technik uprawy (np. zwalczanie chwastów przed siewem lub sadzeniem roślin, termin i norma wysiewu, stosowanie wsiewek, uprawa bezorkowa, cięcie i siew bezpośredni),

- w odpowiednich przypadkach stosowanie odmian odpornych/tolerancyjnych i materiału siewnego i nasadzeniowego kategorii standard/kwalifikowany,

- stosowanie zrównoważonego nawożenia, wapnowania i nawadniania/odwadniania,

- stosowanie środków higieny (np. regularne czyszczenie maszyn i sprzętu), by zapobiec rozprzestrzenianiu się organizmów szkodliwych,

- ochrona i stwarzanie warunków dla występowania ważnych organizmów pożytecznych, np. poprzez stosowanie odpowiednich metod ochrony roślin lub wykorzystywanie ekologicznych struktur w miejscu produkcji i poza nim.”6

Z zasad tych wynika prymat metod biologicznych, fizycznych i innych metod niechemicznych nad metodami chemicznymi, jeżeli te pierwsze zapewniają zadowalającą ochronę przed organizmami szkodliwymi. ${ }^{7}$

$\mathrm{Na}$ marginesie warto zaznaczyć, że przyjęty w Polsce termin ,integrowana ochrona roślin”, będący tłumaczeniem terminu angielskiego - „Integrated Pest Management" - nie stanowi literalnego odzwierciedlenia tego wyrażania. Dosłownie oznacza ono bowiem ,integrowane zarządzanie agrofagami”, co nie ogranicza się tylko do aspektu ich zwalczania - jak może sugerować termin „ochrona”. ${ }^{8}$

Założeniem integrowanej ochrony roślin jest wykorzystywanie w pierwszej kolejności metod niechemicznych, a dopiero w ostateczności metody chemicznej. Wykorzystywane do ochrony roślin metody niechemiczne można podzielić na następujące grupy':

Ust. 1 załącznika nr III do Dyrektywy Parlamentu Europejskiego i Rady 2009/128/WE.

7 Ust. 4 załącznika nr II do Dyrektywy Parlamentu Europejskiego i Rady 2009/128/WE.

8 A.S. Zaliwski, Integrowana ochrona roślin. System doradztwa w zakresie zrównoważonej produkcji roślinnej, IUNG-PIB Puławy, dostępny na: http://www.dss.iung.pulawy.pl, stan z dnia 28.07.2014 r.

9 M. Tomalak, D. Sosnowska, J.J. Lipa, Tendencje rozwoju metod biologicznych w ochronie roślin, „Progress in Plant Protection/Postępy w Ochronie Roślin" 2010, nr 50 (4), s. 1651. 
1) metody agrotechniczne - są to metody, w których wykorzystywany jest odpowiedni dobór stanowiska, gatunków lub odmian uprawianych roślin oraz ich zmianowania, jak też dobór metod uprawy gleb, sposobu i czasu siewu lub sadzenia, nawożenia, terminów zbiorów itp.,

2) metody mechaniczne i fizyczne - są to metody oparte o techniczne sposoby ograniczania występowania agrofagów - takie jak ręczne lub mechaniczne usuwanie, korzystanie z pułapek (świetlnych, lepowych), zapór fizycznych (siatek włóknin, wysokich lub niskich temperatur, itp.),

3) metody biologiczne - są to metody, w których wykorzystanie znajdują wirusy i inne pożyteczne organizmy, występujące w środowisku naturalnym, jak też środki biologiczne i biotechniczne, które zabijają lub konkurują z agrofagami.

Z kolei metoda chemiczna wiąże się ze stosowaniem chemicznych środków ochrony roślin. W ramach integrowanej ochrony roślin winno być ono ograniczone do niezbędnego minimum, a wybierane preparaty powinny charakteryzować się jak najmniejszym ryzykiem niepożądanego wpływu ubocznego na środowisko, działaniem selektywnym, stwarzać jak najmniejsze ryzyko uodpornienia się agrofagów oraz mieć stosunkowo krótki okres zalegania i wiązać się z minimalnymi pozostałościami w środowisku. ${ }^{10}$ Powszechnie uważa się, że stosowanie związków chemicznych powinno być ograniczone między innymi ze względu na:

- negatywny, długotrwały wpływ niektórych związków chemicznych na środowisko (przenikanie do wód gruntowych, niszczenie pożytecznych organizmów),

- ograniczoną skuteczność środków chemicznych w niektórych typach upraw (szklarnie, sady),

- uodparnianie się agrofagów na związki chemiczne. ${ }^{11}$

Nie jest jednak możliwa rezygnacja z metod chemicznych, chociażby ze względu na jej wyższą skuteczność, niższą cenę i prostszą aplikację odpowiednich preparatów. Agrofagi mają ogromne, praktycznie nieograniczone możliwości rozmnażania się i niszczenia roślin. Gdyby agrofagom pozostawić nieograniczone możliwości rozmnażania, to (przy założeniu przetrwania) prowadziłoby to do wzrostu liczebności populacji zgodnie z krzywą wykładniczą. I tak np. jedna para much, która rozmnażałaby się w sposób nieograniczony przez siedem miesięcy, pokryłaby kulę ziemską równomierną warstwą grubości ponad 13 metrów. ${ }^{12}$

F. Kaszak, Integrowana ochrona roślin, http://www.bauernverband-uer.de, dostęp dnia 23.01.2015 r.

M. Tomalak, Tendencje..., op. cit., s. 1651.

R.F. Norris, E.P. Caswell-Chen, M. Kogan, Concepts in Integrated Pest Management, New Jersey 2003. 


\section{Metoda biologiczna}

Szczególnie interesujące i przyszłościowe są biologiczne metody ochrony roślin. Zajmują one stałe miejsce w praktyce ochrony roślin i zyskują coraz więcej zwolenników. Już w starożytnym Egipcie stosowano metodę zwalczania jednego organizmu drugim. Koty hodowano między innymi po to, aby zjadały myszy i aby chronić w ten sposób plony. Podobnie działają też współczesne środki ochrony biologicznej roślin. ${ }^{13}$ Biologiczna ochrona roślin, która stanowi nieodłączną część integralnej ochrony roślin polega więc na użyciu jednego organizmu, aby zredukować populację innego organizmu; dotyczy to zwierząt oraz roślin. ${ }^{14}$ Wykorzystuje się w niej naturalnych wrogów agrofagów, aby zmniejszyć ich populację. Powszechne stosowanie metod biologicznych ma już ponad 100-letnią tradycję. Typowym przykładem sukcesu takich działań jest introdukcja do Kalifornii pod koniec XIX wieku biedronki do zwalczania czerwca białego (groźnego szkodnika drzew cytrusowych $^{15}$ ).

Ponadto, mimo iż stosowanie biologicznych środków ochrony roślin jest dużo bardziej bezpieczne niż stosowanie środków chemicznych, to przy ich stosowaniu pojawiają się pewne ryzyka dotyczące przede wszystkim zmian w środowisku naturalnym. Introdukcje są również obarczone ryzykiem. Klasyczny przykład takiego ryzyka to introdukcja ślimaka Euglandinarosea w 1950 r. na wielu wyspach na Pacyfiku i Oceanie Indyjskim, którą przeprowadzono w celu kontrolowania populacji inwazyjnego ślimaka Achatinafulica. Ta introdukcja spowodowała jednak wymarcie wielu ślimaków drzewnych na tych wyspach. ${ }^{16}$. Pojawiają się więc potencjalne ryzyka dotyczące zdrowia ludzi, zwierząt oraz stanu środowiska, których wyeliminowaniu służą różnego rodzaju ograniczenia związane $\mathrm{z}$ wprowadzaniem danych środków, chemicznych, czy też biologicznych, do obrotu.

Do zalet stosowania metody biologicznej należy zaliczyć zwłaszcza ${ }^{17}$ :

- szczególnie wysoką skuteczność środków biologicznych w niektórych typach upraw (np. pieczarkarnie, szklarnie),

- wysoką selektywność środków biologicznych,

13 A. Augustyniak-Kram, Organizmy pożyteczne w strategiach biologicznego zwalczania - grzyby owadobójcze, „Studia Ecologiae et Bioeticae" 2010, nr 8 (1), s. 45-54.

14 Biological control (biocontrol) is an integral component of IPM. It refers to the use an organism to reduce the population density of another organism and includes the control of animals, weeds and diseases, I. HoescheleZeledon, P. Neuenschwander, L. Kumar, Regulatory challenges for biological control, dostępny na: http://www. spipm.cgiar.org/c/document_library

15 M.E.N. Majerus, Ladybirds, London 1994.

16 Introduction of rosy wolfsnail euglandina rosea released in 1950s in many Pacific and Indian Ocean Islands to control the invasive giant African land snail Achatina fulica. This introduction led to extinction of many tree snail species in these places, C. Regnier, B. Fontaine, P. Bouchet, Not knowing, not recording, not listing: numerous unnoticed mollusk extintions, „Conservation Biology” 23 (2009) 5: 1214-1221.

17 M. Tomalak, Tendencje..., op. cit.; idem, Czynniki biologiczne w integrowanej ochronie roślin, „Progress in Plant 
- wysoki poziom bezpieczeństwa dla konsumenta, chronionej żywności oraz środowiska,

- szczególne wymagania konsumentów, importerów itp. (np. żywność ekologiczna, żywność dla małych dzieci),

- szczególne wymagania związane z ochroną środowiska (ujęcia wodne, tereny zieleni miejskiej, lasy),

- zdolność większości czynników biologicznych do aktywnego odszukiwania agrofaga $\mathrm{w}$ środowisku rolniczym,

- możliwe przedłużone działanie dzięki samoreprodukcji.

Korzyści wynikające ze stosowania metod biologicznych można podzielić na trzy zasadnicze grupy:

1) korzyści związane z ochroną środowiska (ograniczenie stosowania środków chemicznych),

2) korzyści związane $z$ bezpieczeństwem i higieną pracy,

3) korzyści związane z produkcją zdrowej żywności.

Biologiczna ochrona roślin ma szczególne znaczenie dla upraw pod osłonami, gdzie technologia ochrony roślin wymaga zużycia od kilku do kilkudziesięciu kilogramów pestycydów na jeden hektar w ciągu roku, w zależności od gatunku rośliny i zagrożenia ze strony szkodników i chorób. Introdukcja naturalnych wrogów agrofagów powoduje, że liczba zabiegów chemicznych jest zredukowana do kilku lub w niektórych wypadkach nawet do zera.

Jednocześnie jednak pamiętać należy, że stosowanie praktyk biologicznych w ochronie roślin wymaga często dużo większej wiedzy niż stosowanie środków chemicznych. ${ }^{18}$

Obecnie biologiczne środki ochrony roślin stanowią mniej niż $1 \%$ wartościowo rynku środków ochrony roślin. Nadal zdecydowanie przoduje ochrona chemiczna. Jednak działania związane $\mathrm{z}$ wprowadzaniem instytucjonalnych rozwiązań, takich jak omawiane powyżej regulacje europejskie, z pewnością zwiększą popularność tego rodzaju ochrony, korzystniejszej dla konsumenta i dla środowiska.

\section{Regulacja polska}

W Polsce już od 1919 roku podejmowano działania zmierzające do uregulowania stosowania środków chemicznych w zwalczaniu organizmów szkodliwych.

C. Alabouvette, C. Olivain, C. Steinberg, Biological Control of Plant Diseases: The European Situation, „European Journal of Plant Pathology” 2006, t. 114, s. 329-341: Biological control practices need an integrative approach, and more knowledge than chemical control. 
Podstawowymi aktami prawnymi w tym temacie były Zasadnicza Ustawa Sanitarna z dnia 19 lipca 1919 r. ${ }^{19}$ oraz Rozporządzenie Ministra Spraw Wewnętrznych i Ministra Przemysłu i Handlu z dnia 16 listopada 1924 r. o wyrobie i sprzedaży środków przeznaczonych do trucia szczurów, myszy, owadów, pasożytów zwierzęcych i innych. ${ }^{20} \mathrm{~W}$ rozporządzeniu tym wprowadzono system wydawania zezwoleń na wyrabianie i wprowadzanie do obrotu tego typu preparatów, a także ustalono pierwsze wymagania w zakresie treści etykiety, oznakowania, a także przechowywania i sprzedaży. ${ }^{21}$

Po II Wojnie Światowej zasady rejestracji środków ochrony roślin określono w ustawie z dnia 16 lutego 1961 roku o ochronie roślin uprawnych przed chorobami, szkodnikami i chwastami. ${ }^{22} \mathrm{Na}$ obrót i stosowanie chemicznych środków ochrony roślin zezwolenie musiał wydać Minister Rolnictwa. W roku 1965 do obrotu i stosowania dopuszczono w Polsce 190 środków ochrony roślin. Liczba ta systematycznie zwiększała się w latach kolejnych i w roku 1994 wynosiła już 562. ${ }^{23}$

Przystąpienie Polski do Unii Europejskiej znacząco wpłynęło na zmianę przepisów i praktyki w zakresie rejestracji i co za tym idzie dopuszczania środków ochrony roślin do obrotu i ich stosowania. Dostosowanie obowiązujących regulacji do Dyrektywy Rady z dnia 15 lipca 1991 roku nr 91/414/EWG dotyczącej wprowadzania do obrotu środków ochrony roślin ${ }^{24}$ wiązało się ze wzrostem liczby badań środowiskowych i toksykologicznych, prowadzonych na koszt producentów, jak też dopuszczenia do obrotu i stosowania tylko takich substancji aktywnych, które zostały wpisane do załącznika nr 1 do powyższej Dyrektywy. ${ }^{25}$

Od 1 stycznia 2014 r. Polska zobowiązana jest do stosowania najnowszych regulacji unijnych, tj. Dyrektywy Parlamentu Europejskiego i Rady 2009/128/ WE z dnia 21 października 2009 roku ustanawiającej ramy wspólnotowego działania na rzecz zrównoważonego stosowania pestycydów oraz rozporządzenia Parlamentu Europejskiego i Rady (WE) nr 1107/2009 z dnia 21 października 2009 r. dotyczącego wprowadzenia do obrotu środków ochrony roślin i uchylającego Dyrektywy Rady 79/117/EWG i 91/414/EWG. Polska zobowiązana jest więc także stosować wspomniane wcześniej ogólne zasady integrowanej ochrony roślin, wynikające z załącznika nr III do Dyrektywy 2009/128/WE.

Dz.U. z 1919 r. Nr 63, poz. 371.

Dz.U. z 1924 r. Nr 105, poz. 955.

S. Pruszyński, Wpływ regulacji prawnych UE na prace komisji do spraw rejestracji środków ochrony roślin przy Ministerstwie Rolnictwa i Rozwoju Wsi, http://www.ior.poznan.pl, stan z dnia 28.07.2014 r.

Dz.U. z 1961 r. Nr 10, poz. 55

S. Pruszyński, Wpływ regulacji..., op. cit.

Dz.Urz. UE L 230 z 19.08.1991 r., s. 1.

S. Pruszyński, Wpływ regulacji..., op. cit. 
Wyrazem wprowadzenia powołanych regulacji do polskiego porządku prawnego jest przede wszystkim ustawa $\mathrm{z}$ dnia 8 marca 2013 r. o środkach ochrony roślin. ${ }^{26}$ Zgodnie z powołaną ustawą z dniem 1 stycznia 2014 r. stosowanie integrowanej ochrony roślin stało się obowiązkiem wszystkich profesjonalnych użytkowników środków ochrony roślin. Szczegółowe wymagania w tym zakresie określone zostały w rozporządzeniu Ministra Rolnictwa i Rozwoju Wsi z dnia 18 kwietnia 2013 r. W sprawie wymagań integrowanej ochrony roślin ${ }^{27}$. W związku z wprowadzonymi regulacjami, w zależności od typu upraw, spełnione muszą być wymagania w zakresie:

- stosowania płodozmianu, terminu siewu lub sadzenia lub obsady roślin, w sposób ograniczający występowanie organizmów szkodliwych,

- stosowania agrotechniki w sposób ograniczający występowanie organizmów szkodliwych, w tym stosowanie mechanicznej ochrony roślin,

- wykorzystywania odmian odpornych lub tolerancyjnych na organizmy szkodliwe oraz materiału siewnego wytworzonego i poddanego ocenie zgodnie $\mathrm{z}$ przepisami o nasiennictwie,

- stosowania nawożenia, nawadniania i wapnowania, w sposób ograniczający występowanie organizmów szkodliwych,

- przeprowadzania czyszczenia i dezynfekcji maszyn, opakowań i innych przedmiotów, zapobiegającego występowaniu i rozprzestrzenianiu się organizmów szkodliwych,

- ochrony organizmów pożytecznych oraz stwarzania warunków sprzyjających ich występowaniu, w szczególności dotyczy to owadów zapylających i naturalnych wrogów organizmów szkodliwych. ${ }^{28}$

Ponadto osoby wykonujące zabiegi chemicznej ochrony roślin muszą dobierać środki ochrony w taki sposób, aby minimalizować ich negatywny wpływ na środowisko, ograniczać liczbę zabiegów i ilość środków do koniecznego minimum oraz przeciwdziałać uodparnianiu się organizmów szkodliwych na stosowane środki ochrony (poprzez ich właściwy dobór i przemienne stosowanie).

\section{Krajowy Plan Działania}

Zgodnie z art. 4 Dyrektywy Parlamentu Europejskiego i Rady 2009/128/ WE z dnia 21 października 2009 r. ustanawiającej ramy wspólnotowego działania na rzecz zrównoważonego stosowania pestycydów państwa członkowskie Unii

Dz.U. z 2013 r., poz. 455.

Dz.U. z 2013 r., poz. 505.

Komunikat Głównego Inspektora Ochrony Roślin i Nasiennictwa z dnia 3 stycznia 2014 r., https://piorin.gov.pl/index.php?pid=2160, dostęp dnia 28.07.2014 r. 
Europejskiej mają obowiązek ustanowienia krajowych planów działania służących ustalaniu celów, środków i harmonogramów zmierzających do zmniejszenia zagrożenia związanego ze stosowaniem środków ochrony roślin. Krajowe plany działania mają na celu ustalenie celów ilościowych, środków, miar, harmonogramów i wskaźników zmierzających do zmniejszenia zagrożenia związanego ze stosowaniem pestycydów i wpływu ich stosowania na zdrowie ludzi i na środowisko oraz zachęcanie do opracowania i stosowania integrowanej ochrony roślin i alternatywnych podejść lub technik mających na celu zmniejszenie zależności od stosowania pestycydów. W krajowych planach działania państwa członkowskie Unii Europejskiej powinny także opisać, w jaki sposób będą wdrażały postanowienia art. 5-15 dyrektywy 2009/128/WE, dotyczące w szczególności:

1) ustanowienia systemu szkoleń dla profesjonalnych użytkowników środków ochrony roślin, dystrybutorów tych preparatów oraz doradców świadczących usługi w zakresie ochrony roślin;

2) podnoszenia świadomości ogółu społeczeństwa odnośnie środków ochrony roślin;

3) zapewnienia nadzoru nad stanem technicznym sprzętu przeznaczonego do stosowania środków ochrony roślin, będącego w użytkowaniu;

4) ochrony środowiska wodnego i wody pitnej przed skażeniem środkami ochrony roślin;

5) ograniczenia stosowania środków ochrony roślin lub zagrożeń wynikających $\mathrm{z}$ ich stosowania;

6) na obszarach dostępnych dla szczególnie wrażliwych grup ludności oraz na obszarach cennych przyrodniczo;

7) wdrożenia zasad integrowanej ochrony roślin przez profesjonalnych użytkowników środków ochrony roślin;

8) monitorowania ryzyka związanego ze stosowaniem środków ochrony roślin.

Krajowy Plan działania dla Polski został opublikowany w Obwieszczeniu Ministra Rolnictwa i Rozwoju Wsi z dnia 6 maja 2013 r. w sprawie krajowego planu działania na rzecz ograniczenia ryzyka związanego ze stosowaniem środków ochrony roślin ${ }^{29}$.

\section{Podsumowanie}

Integrated pest management (IPM, Integrowana ochrona roślin) jest wyrazem nowego podejścia do środków ochrony roślin. Mamy do czynienia z przewartościo- 
waniem celów, którym takie środki mają służyć. ${ }^{30}$ Nadrzędną wartością staje się zdrowie ludzkie i ochrona środowiska, a nie maksymalizacja produkcji. Wyrazem tego rodzaju tendencji jest nowe ustawodawstwo Unii Europejskiej, w którym widoczne jest wskazanie, iż ochrona zdrowia ludzi i zwierząt oraz ochrona środowiska ma pierwszeństwo przed zwiększeniem poziomu produkcji. Przepisy dotyczące IPM stanowią ważny krok w zapewnieniu bezpieczeństwa ludziom i środowisku naturalnemu. Szereg rozwiązań zawartych w przepisach, takich jak promowanie zmniejszania zależności od ochrony chemicznej, kontrola stosowania przez rolników chemicznych środków ochrony roślin, rozwój doradztwa rolniczego, system szkoleń, tworzenie ośrodków informacyjnych, należy uznać za bardzo pozytywne. Konieczne jest zapewnienie środków na ten cel, jednak w ramach programów unijnych takie środki z pewnością się znajdą.

Bardzo istotną częścią IPM jest rozwój zastosowania biologicznych środków ochrony roślin. Ich obecny udział w ogólnym rynku środków ochrony roślin wynosi około 4\%, jest więc niewielki. Nowa legislacja z pewnością doprowadzi jednak do znacznego wzrostu ich wykorzystywania oraz zmian jakościowych, wprowadzania nowych, bardziej efektywnych i tańszych środków.

Podkreślić należy, iż przy wdrażaniu nowych rozwiązań najwięcej będzie zależało od rzeczywistego stosowania przepisów unijnych i wewnętrznych przez rolników oraz odpowiednie organy administracji. Przestrzeganie zasad IPM, promocja biologicznych środków ochrony roślin, powinny stać się częścią rolnej kultury krajów Unii Europejskiej, dla dobra konsumentów i środowiska. 
REGULATIONS RELATING TO THE INTEGRATED PEST MANAGEMENT

Keywords: Integrated pest management, integrated plant protection, biological control agents, plant protection products

Since January 1,2014 all EU member states have been obliged to observe principles of the Integrated Pest Management. In the article the basic premises of the new regulation are presented. According to them, it is indispensable to replace chemical plant protection products by other means, among others, biological ones. The author discusses basic regulations concerning registration of biological plant protection means in the EU and in Poland. It is to be admitted that the introduction of the IPM constitutes a big step towards integration of solutions functioning in the EU state members. The new regulation will certainly ensure better security in application of plant protection products and in restriction of use of chemicals. 